\title{
Pengaruh Kemampuan Verbal dan Kemampuan Numerik terhadap Prestasi Belajar Matematika Siswa SMPS Katolik Aurora Kefamenanu
}

\section{Yuliana L. Nahak a , Stanislaus Amsikan ${ }^{\text {b }}$, Eva Binsasi ${ }^{\mathrm{c}}$}

${ }^{a}$ Fakultas Ilmu Pendidikan, Universitas Timor, Kefamenanu, TTU - NTT, Indonesia.

${ }^{b}$ Fakultas Ilmu Pendidikan, Universitas Timor, Kefamenanu, TTU - NTT, Indonesia.

cFakultas Pertanian,Universitas Timor, Kefamenanu, TTU - NTT, Indonesia.

\section{Article Info}

Article history:

Received 31 Juli 2018

Received in revised form 10 Juni 2019

Accepted 26 Juni 2019

DOI:

https://doi.org/10.32938/slk.v2i1.442

Keywords:

Kemampuan verbal, kemampuan numerik

dan prestasi belajar matematika.

\section{Abstrak}

Kemampuan verbal dan kemampuan numerik adalah kompetensi yang dibutuhkan dalam mempelajari matematika dan diduga berpengaruh terhadap prestasi belajar matematika siswa. Penelitian ini bertujuan untuk melihat ada tidaknya pengaruh kemampuan verbal dan kemampuan numerik terhadap prestasi belajar matematika siswa SMP baik secara parsial maupun simultan. Penelitian dilakukan di SMPS Katolik Aurora Kefamenanu Tahun Ajaran 2017/2018. Instrumen yang digunakan yaitu tes kemampuan verbal, tes kemampuan numerik dan tes prestasi belajar matematika. Berdasarkan hasil analisis data maka dapat disimpulkan bahwa 1) Secara parsial terdapat pengaruh yang signifikan antara kemampuan verbal dan kemampuan numerik terhadap prestasi belajar matematika siswa SMP. 2) Secara simultan terdapat pengaruh yang signifikan antara kemampuan verbal dan kemampuan numerik terhadap prestasi belajar matematika siswa. Berdasarkan hasil tersebut dapat disimpulkan bahwa baik secara parsial maupun simultan terdapat pengaruh antara kemampuan verbal dan kemampuan numerik terhadap prestasi belajar siswa SMP.

\section{Pendahuluan}

Matematika adalah bahasa yang melambangkan makna dari penyataanpernyataan, atau lambang-lambang matematika yang bersifat artifisial artinya simbol-simbol baru memiliki arti apabila diberi makna. Sifat artifisial simbol-simbol matematika bersifat individual yang bertumpu pada kesepakatan. Hasil kesepakatan tentang simbol-simbol matematika dirumuskan sebagai bahasa matematika yang bersifat universal artinya dimana dan kapan saja simbol matematika memiliki makna yang sama. Matematika dipandang sebagai bahasa karena "dalam matematika terdapat sekumpulan lambang/simbol dan kata (baik kata dalam bentuk lambang)". Simbol-simbol matematika dapat berupa kata-kata maupun lambang yang disebut angka, sehingga belajar matematika membutuhkan kemampuan verbal maupun kemampuan numerik.

Kemampuan verbal merupakan kemampuan untuk memahami hubungan kata, kosakata dan menerima dengan cepat kata-kata tertentu termasuk kemampuan mengingat kata-kata dan pola yang membentuknya. Kemampuan verbal dan kemampuan numerik adalah kompetensi yang dibutuhkan dalam mempelajari matematika. Kemampuan verbal membantu siswa untuk memahami hubungan kata, kosakata, sehingga siswa dapat memahami dan mengkomunikasikan serta menyelesaikan masalah-masalah matematika. Salah satu aspek logika yang dibutuhkan untuk belajar matematika adalah kemampuan verbal yang memungkin siswa untuk memahami dan menginterpretasikan masalah-masalah yang ditemukan. Kemampuan verbal akan membantu siswa dalam memahami makna dan membuat model matematika untuk menyelesaikan masalah matematika, sebaliknya apabila kemampuan verbal siswa kurang baik, maka siswa juga akan sulit dalam menyelesaikan soal matematika sehingga secara tidak langsung akan berdampak pada pencapaian prestasi belajar.

Salah satu aspek dalam belajar matematika dan aktivitas matematika adalah kemampuan numerik. Kemampuan numerik merupakan kemampuan standar tentang angka dan kemampuan melakukan perhitungan-perhitungan yang juga merupakan bagian dari aktivitas matematika (Saeful dalam Irawan \& Kencanawaty, 2016). Kedudukan kemampuan numerik sebagai dasar yang menjadi standar untuk belajar matematika dibutuhkan kecepatan dan ketepatan dalam melakukan operasi bilangan. Menurut Irawan (2015:49) dalam (Irawan, 2016), kecerdasan numerik adalah kecerdasan dalam menggunakan angka-angka dan penalaran (logika) meliputi di bidang matematika, mengklasifikasikan dan mengategorikan informasi berpikir dengan konsep abstrak untuk menemukan hubungan antara suatu hal dengan hal lainnya. Dengan demikian maka dapat disimpulkan bahwa kemampuan numerik adalah kemampuan seseorang dalam menggunakan angka-angka untuk menemukan solusi setelah dilakukan kalsifikasi dari suatu konsep abstrak. Menurut Olatoye \& Aderogba (Daniyati \&Sugiman, 2015) untuk mencapai prestasi belajar yang baik, mereka harus memiliki kemampuan verbal dan kemampuan numerik yang baik.

\section{Metode}

\subsection{Waktu dan Tempat}

Penelitian dilaksanakan di SMPS Katolik Aurora, Kabupaten Timor Tengah Utara (TTU) pada semester Genap Tahun Ajaran 2017/2018.

\subsection{Rancangan Penelitian}

Populasi sebanyak 35 siswa kelas VIII SMPS Katolik Aurora Kefamenanu dan secara acak dipilih 32 siswa sebagai sampel. Variabel penelitian yaitu variabel bebas berupa kemampuan verbal $\left(X_{1}\right)$ dan kemampuan numerik $\left(X_{2}\right)$ dan variabel terikat berupa prestasi belajar matematika $(Y)$. Instrumen yang digunakan yaitu tes untuk mengukur prestasi belajar matematika siswa, serta tes kemampuan verbal dan kemampuan numerik siswa.

\subsection{Prosedur Kerja}

Data kemampuan verbal, kemampuan numerik dan prestasi belajar siswa yang diperoleh kemudian diolah menggunakan sofftware SPSS 20.00.

\subsection{Strategi Analisis Data}

Teknik analisadata menggunakan analisis regresi linier sederhana untuk menentukan besarnya pengaruh variabel $X_{1}$ dan $X_{2}$ terhadap $Y$ secara partial, dan analisis regresi berganda untuk menentukan besarnya pengaruh variabel $X_{1}$ dan $X_{2}$ terhadap $Y$ secara simultan. Langkah-langkah analisisnya sebagai berikut:

2.4.1 Melakukan uji prasyarat, yaitu uji normalitas dan multikolinearitas data.

a. Uji normalitas, bertujun untuk menguji apakah data kemampuan verbal, kemampuan numerik maupun prestasi belajar siswa berdistribusi normal atau tidak dengan statistik uji yang digunakan adalah chi-square yaitu sebagai berikut (Sudjana, 1996):

$$
\chi^{2}=\sum_{i=1}^{k} \frac{\left(O_{i}-E_{i}\right)^{2}}{E_{i}}
$$

Keterangan:

$O_{i}=$ frekuensi pengamatan

$E_{i}=$ frekuensi harapan 
b. Uji multikolinieritas digunakan untuk memenuhi persyaratan analisis regresi ganda yaitu untuk mengetahui apakah terdapat hubungan (korelasi) yang signifikan antar variabel bebas. Multikolinieritas antar variabel bebas terjadi bila koefisien korelasi antara variabel bebas sama dengan atau lebih besar dari 0,800 . Teknik statistik yang digunakan adalah korelasi Product Moment dari Pearson.

2.4.2 Menentukanpersamaan regresi sederhana dan berganda

a. Persamaan Regresi Sederhana

a) Menentukan koefisien regresi sederhana

Analisis regresi sederhana bertujuan untuk menentukan pengaruh masing-masing variabel bebas $X_{1}$ dan $X_{2}$ terhadap variabel terikat $Y$ (Riduwan, 2010):

(a) Kemampuan Verbal

$$
\hat{Y}=a+b X_{1}
$$

(b) Kemampuan Numerik

$$
\hat{Y}=a+b X_{2}
$$

dengan:

$a=\frac{\sum Y-b \sum X}{n} \operatorname{dan} b=\frac{n \sum X Y-\sum X \sum Y}{n \sum X^{2}-\left(\sum X\right)^{2}}$

$\hat{Y}=$ subjek variabel terikat yang dicari

$X=$ variabel bebas yang mempunyai nilai tertentu untuk diprediksi

$a=$ nilai konstanta harga $Y$ jika $X=0$

$b=$ nilai arah yang menunjukan nilai meningkat atau menurun variabel $Y$.

b)Uji signifikansi

Uji $t$ digunakan untuk menguji pengaruh variabel $X_{1}$ dan $X_{2}$ terhadap variabel $Y$ secara partial (Riduwan, 2010).

$$
t=r \sqrt{\frac{n-2}{1-r^{2}}}
$$

Keterangan:

$t=$ statistik $\mathrm{t}$ dengan derajat bebas $n-2$

$r=$ koefisien regresi

$n=$ banyaknya pengamatan

Hipotesis yang akan diuji:

(a) Hipotesis untuk uji kemampuan verbal.

Ho: Tidak ada pengaruh kemampuan verbal terhadap prestasi belajar matematika

Ha:Ada pengaruh kemampuan verbal terhadap prestasi belajar matematika

(b) Hipotesis untuk uji kemampuan numerik

Ho:Tidak ada pengaruh kemampuan numerik terhadap prestasibelajar matematika

Ha:Ada pengaruh kemampuan numerikterhadap prestasibelajar matematika

(c) Kriteria pengujian signifikansi: Ho ditolak Jika $t_{\text {hitung }}>t_{\text {tabel }}$

b. Persamaan Regresi Berganda

a) Menentukan koefisien regresi berganda

Persamaan regresi ganda bertujuan untuk memprediksi pengaruh variabel independen terhadap variabel dependen secara simultan.

Model persamaan regresi ganda tersebut adalah sebagai berikut:

$$
\hat{Y}=a+b_{1} X_{1}+b_{2} X_{2}
$$

Keterangan:

$\hat{Y}=$ prediksi prestasi belajar siswa
$X_{1}, X_{2}$ =variabel-variabel bebas (kemampuan verbal dan kemampuan numerik siswa)

$a=$ konstanta

$b 1, b 2=$ koefisien regresi

dengan:

$a=\frac{\sum Y}{n}-b_{1} \cdot\left(\frac{\sum X_{1}}{n}\right)-b_{2} \cdot\left(\frac{\sum X_{2}}{n}\right)$

$b_{1}=\frac{\left(\sum x_{2}^{2}\right) \cdot\left(\sum x_{1} y\right)-\left(\sum x_{1} x_{2}\right) \cdot\left(\sum x_{2} y\right)}{\left(\sum x_{1}^{2}\right) \cdot\left(\sum x_{2}^{2}\right)-\left(\sum x_{1} x_{2}\right)^{2}}$

$b_{2}=\frac{\left(\sum x_{1}^{2}\right) \cdot\left(\sum x_{2} y\right)-\left(\sum x_{1} x_{2}\right) \cdot\left(\sum x_{1} y\right)}{\left(\sum x_{1}^{2}\right) \cdot\left(\sum x_{2}^{2}\right)-\left(\sum x_{1} x_{2}\right)^{2}}$

b) Uji signifikansi

Uji $F$ digunakan untuk menguji pengaruh variabel $X_{1}$ dan $X_{2}$ terhadap variabel $Y$ secara simultan. Rumus yang digunakan:

$F=\frac{R^{2} / k}{\left(1-R^{2}\right) /(N-K-1)}$.

(a) Hipotesis yang diuji:

Ho: Tidak ada pengaruh secara simultan kemampuan verbal dan kemampuan numerik terhadap prestasi belajar matematika.

Ha:Ada pengaruh secara simultan kemampuan verbal dan kemampuan numerik terhadap prestasi belajar matematika.

(b) Hipotesis statistik

Ho: $\rho=0$ (tidak ada pengaruh signifikan)

Ha: $\rho \neq 0$ (ada pengaruh signifikan)

(c) Kriteria pengujian signifikansi:Ho ditolak Jika $F_{\text {hitung }}>F_{\text {tabel. }}$.

3. Menghitung indeks determinasi

Indeks determinan bertujuan untuk menentukan besarnya pengaruh variabel bebas $X_{1}$ dan $X_{2}$ terhadap variabel terikat $(Y)$. Rumus yang digunakan adalah:

$$
I=R^{2} \times 100 \%
$$

\section{Hasil dan Pembahasan}

Pengolahan data menggunakan SPSS versi 20.00, diperoleh hasil sebagai berikut:

\subsection{Uji prasyarat}

Hasil uji normalitas diberikan pada tabel 1 berikut.

Tabel 1. Hasil Uji Normalitas

\begin{tabular}{|l|c|}
\hline \multicolumn{1}{|c|}{ Variabel } & Hasil uji \\
\hline Kemampuan verbal $\left(X_{1}\right)$ & 0,2 \\
\hline Kemampuan numerik $\left(X_{2}\right)$ & 0,87 \\
\hline Prestasi belajar $(Y)$ & 0,18 \\
\hline
\end{tabular}

Berdasarkan hasil uji pada tabel 1, dengan $\alpha=5 \%$ maka dapat disimpulkan bahwa kemampuan verbal, kemampuan numerik siswa dan prestasi belajar siswa semuanya berdistribusi normal. Salah satu syarat analisis regresi yaitu multikolinearitas, dimana antara variabel bebas tidak boleh ada hubungan atau korelasi. Hasil pengujian dangan korelasi product moment menunjukkan bahwa nilai VIF kedua variabel 1,863 sehingga antara variabel kemampuan verbal dan kemampuan numerik tidak terjadi multikolinearitas.

\subsection{Persamaan Regresi}

a. Persamaan Regresi Sederhana

Hasil analisis data diperoleh persamaan regresi sederhana $X_{1}$ atas $\mathrm{Y}$ sebagai berikut $\hat{Y}=16,761+0,683 X_{1}$. Konstanta sebesar 16,761 , artinya jika kemampuan verbal $\left(X_{1}\right)=0$, maka prediksi prestasi belajar 
matematika $\operatorname{siswa}(\hat{Y})$ sebesar16,761. Koefisien regresi variabel kemampuan verbal $\left(X_{1}\right)$ sebesar 0,683 , artinya jika kemampuan verbal mengalami peningkatan 1 (satu) satuanmaka hasil belajar matematika siswa akan mengalami peningkatan sebesar 0,683. Koefisien regresi bernilai positif artinya terjadi hubungan positif antara tingkat kemampuan verbal dengan prestasi belajar matematika, yaitu semakin tinggi tingkat kemampuan verbal maka semakin tinggi pula prestasi belajar matematika siswa. Selanjutnya persamaan regresi variabel kemampuan numerik $\left(X_{2}\right)$ dan prestasi belajar matematika sebagai berikut $\hat{Y}=17,787+0,737$. Konstanta sebesar 17,787, artinya jika kemampuan numerik siswa $\left(X_{2}\right)=0$,maka prediksi prestasi belajar matematika siswa $(\hat{Y})$ sebesar 17,787 . Koefisien regresi variabel kemampuan numerik $\left(X_{2}\right)$ sebesar 0,737 , artinya jika kemampuan numerik mengalami peningkatan satu satuan maka hasil belajar matematika siswa akan mengalami peningkatan sebesar 0,737. Koefisien regresi bernilai positif artinya terjadi hubungan positif antara tingkat kemampuan numerik dengan prestasibelajar matematika, semakin tinggi tingkat kemampuan numerik maka semakin tinggi pula prestasibelajar matematika.

b. Persamaan regresi berganda

Persamaan regresi berganda pengaruh kemampuan verbal dan kemampuan numerik terhadap prestasi belajar matematika sebagai berikut: $\hat{Y}=8,847+0,419 X_{1}+0,415 X_{2} . \quad$ Persamaan ini menunjukkan bahwa semakin tinggi atau bertambah kemampuan verbal dan kemampuan numerik siswa maka akan meningkatakan prestasi belajar matematika siswa.

c. Uji signifikansi

Dari persamaan regresi, selanjutnya dilakukan uji signifikansi untuk mengetahui ada tidaknya pengaruh secara parsial kemampuan verbal $\left(X_{1}\right)$ dan kemampuan numerik $\left(X_{2}\right)$ terhadap prestasi belajar matematika $(\hat{Y})$. Dari hasil perhitungan dengan uji $t$ dan uji $F$ diperoleh nilai probabilitas $0,000<0,05$. Hal ini menunjukkan bahwa baik secara parsial maupun secara simultan terdapat pengaruh kemampuan verbal dan kemampuannumerik terhadap prestasi belajar matematika siswa.

\subsection{Nilai Determinasi}

Hasil perhitungan diperoleh nilai kolerasi sebesar 0,69 dengan indeks determinasi atau $R$-Square sebesar $69 \%$ artinya besar sumbangan kemampuan verbal dankemampuannumerik terhadapprestasi belajar matematika siswa adalah $69 \%$, sedangkan 31\% sisanya adalah faktor lain yang turut mempengaruhi hasil belajar matematika siswa tidak dikaji dalam penelitian ini.

\section{Simpulan}

Berdasarkan hasil penelitian dapat disimpulkan bahwa semakin tinggi kemampuan verbal dan kemampuan numerik siswa maka akan semakin tinggi pula prestasi belajar matematika siswa. Hal ini sesuai dengan kajian teori dan kerangka berpikir pada penelitian inidimana kemampuan verbal dan kemampuan numerik mempunyai pengaruh terhadap prestasi belajar matematika siswa SMPS Katolik Aurora Kefamenanu T.A 2017/2018.

\section{Pustaka}

Daniyati \& Sugiman 2015. Hubungan antara Kemampuan Verbal dan Kemampuan Interpersonal dan Minat Belajar Dengan Prestasi

Belajar Matematika. Jurnal Pendidikan Matematika, 6.

Hasbulla.2013.Dasar-dasar Ilmu Pendidikan.Jakarta:Rajawali pers.
Irawan, A. 2016. Peranan Kemampuan Numerik dan Verbal dalam Berpikir Kritis Matematika pada Tingkat Sekolah Menengah Atas. AdMathEdu, 6.

Irawan \& Kencanawaty 2016. Peranan Kemampuan Verbal dan Kemampuan Numerik Terhadap Kemampuan Kritis Matematika Jurnal Pendidikan Matematika FKIP Univ. Muhamadiyah Metro, 5 .

Nizoloman. 2013. Relationship Between Mathematical Ability and Achievement in Mathematics Among Female Secondary School Students In Bayesla State Nigeria.Procedia-social and Behavioral Science s. No.106

Riduwan 2010. Dasar- Dasar Statistika. Bandung: Alfabeta.

Sagala.2010. Konsep dan Makna Pembelajaran. Bandung:Alfabeta

Slameto. 2003. Belajar dan Faktor-faktor yang Mempengaruhinya. Jakarta: Rineka Cipta

Sudjana 1996. Teknik Analisis Regresi Dan korelasi. Bandung: Tarsito. 